\title{
Odonata drift: a reassessment
}

\author{
Robert B. DuBois* \\ Department of Natural Resources, Bureau of Natural Heritage Conservation, Superior, Wisconsin, USA
}

(Received 1 May 2020; final version received 31 August 2020)

\begin{abstract}
More than 400 scientific journal articles and gray literature reports that addressed macroinvertebrate drift were reviewed and 63 articles were found that reported on the natural drift of Odonata at some taxonomic level. Forty-three species and 44 genera within 15 families (nine Zygoptera; six Anisoptera) were documented in the drift. Drift of another 13 species and eight genera was inferred from indirect evidence. The mean drift density reported was $0.03 \mathrm{~m}^{-3}$ (range $<0.001-0.153 \mathrm{~m}^{-3}$ ), which is relatively low, but not unexpected because benthic densities of Odonata are often lower than those of the macroinvertebrate taxa that occur more frequently in the drift. Percent composition of odonates in the total drift was invariably $<10 \%$ and usually $<1 \%$, but the percent was slightly higher if expressed as biomass or volume because odonate larvae are relatively large. Most odonates that drifted were not full grown. High flows were often associated with drift of Odonata, but not exclusively so; drift was highest at night and during summer months. Accidental (catastrophic) drift and active, behavioral drift to colonize new habitats and reduce crowding are thought to be the primary causes of Odonata drift, but its ecological significance would benefit from more research. The presumption that Odonata have a low predisposition to drift is probably not uniformly accurate. Use of drift nets specifically to collect odonates is unlikely to be as efficient as other collection methods in most circumstances, but it should not be entirely dismissed because drift nets are easy to set, relatively clean to operate, do not destroy habitats, and provide integrated samples of various habitats where it might be difficult or unsafe to use other methods.
\end{abstract}

Keywords: Zygoptera; Anisoptera; drift; review; dragonfly

\section{Introduction}

Many riverine aquatic macroinvertebrates move downstream with the current in sufficient numbers, and with enough frequency, that this drift is generally understood to be an ecologically significant phenomenon (Allan \& Castillo, 2007; Benke, Hunter, \& Parrish, 1986; Müller, 1974; Waters, 1972). However, the ecological mechanisms for drifting behavior are incompletely known, undoubtedly complex, and to some extent controversial (Koetsier \& Bryan, 1995; Müller, 1995). In various settings and with various taxa groups these mechanisms are thought to include escaping from unfavorable environmental conditions, dispersing to colonize new habitats, reducing crowding, and becoming accidently dislodged from the substrate, especially during high flows (reviewed by Brittain \& Eikeland, 1988). Thus, the drift of aquatic macroinvertebrates has active and passive modes as well as diel, seasonal, and taxonomic aspects. Drift has been defined as constant, catastrophic, behavioral, or distributional, but Brittain and Eikeland (1988) warned that much confusion has arisen with these terms and their use should be limited, while Müller

*Email: rbdubois@gmail.com 
(1995) noted that these categories were not always practical because assigning them in specific cases could rarely be done with confidence. In some cases, drift seems to function as a density dependent mechanism whereby excess production is released from a river reach (Dimond, 1967; Fenoglio, Bo, Gallina, \& Cucco, 2004; Waters, 1965), but in other cases no relation is found between the benthic fauna and the drift (Elliott, 1967; Fleituch, 1985; Koetsier \& Bryan, 1996). In any case, odonates are infrequently collected in most drift studies (Müller, 1995), their drift distances are not known, and the reasons for their drift behavior, and the taxa and life stages involved, are also not well known.

Drift is usually sampled by placing a net with a conical shape at a fixed location in a flowing water system for a measured amount of time. This is a passive form of collection, with drifting animals being washed into the net by the current. Although the drift nets commonly used by aquatic entomologists vary somewhat in size, they usually have net openings of about $0.09 \mathrm{~m}^{-2}$, lengths of 80 to $140 \mathrm{~cm}$, and relatively fine mesh sizes of 250-500 $\mu \mathrm{m}$ (Anderwald, Konar, \& Humpesch, 1991). Animals caught in a drift net are funneled into a collection cup at the net's downstream end where they are later removed and identified. If the opening area of the net and the current velocity at the net mouth are measured, then the volume of water sampled per unit time can be calculated. Numbers of drifting animals can be expressed in many ways including drift density (number of animals per volume of water sampled), drift rate (number of animals passing a certain point or the total cross-section of the stream per unit time), relative abundance, percent composition of the drift, or simply numbers or biomasses collected. Among these, drift densities are particularly useful because they are readily comparable among studies, sites, dates, or treatments, and they have often been measured in prior studies. Drift rates can be useful as well, and if current velocities are measured, then drift rates are readily converted to drift densities.

Two main problems have hindered attempts to understand the drift behavior of Odonata. First, because Odonata larvae are usually infrequently collected in drift nets, it is likely that they are sometimes not reported even when some are caught, or the few collected are incidentally included in an "other" or "miscellaneous" category with other uncommonly collected taxa (e.g. Benke et al., 1986; Shannon, Blinn, Benenati, \& Wilson, 1996). The frequency with which Odonata have been pooled with other groups in this way is unknown because not all reports have explicitly stated which taxa were ignored or placed in such a category. It is understandable that odonates might be ignored or pooled with other groups because researchers are often interested in making comparisons among treatments, conditions, sites, or dates, and collecting a few odonates gives little potential for biological insights to be gained in the analyses. In an early synopsis of Nearctic aquatic insect drift, Adamus and Gaufin (1976) reviewed 33 studies and found only three that reported larvae of Odonata. Although many more studies have since reported on drifting Odonata, and dozens of species and genera are now known to drift, the pattern of incomplete reporting of Odonata in drift studies has persisted. A second problem is that when Odonata have been reported, determinations have often been made at various taxonomic levels higher than species. Leaving odonate determinations at high taxonomic levels is also understandable because the larvae can be relatively difficult to identify, especially when not full grown (Tennessen, 2016, 2019). For most aquatic insect groups, partly grown individuals often do most of the drifting (Waters, 1972), which may be the case for Odonata as well. However, when taxonomic determinations are left at higher levels, the usefulness of the data can be reduced because the species level is the fundamental one for addressing issues pertaining to biodiversity. Although incomplete and cursory reporting of Odonata in drift studies is both understandable and inevitable given their usually low numbers and the difficulties in identifying the larvae, the resulting paucity of information has compromised our ability to gain ecological insights into Odonata drift.

Because odonate larvae are collected in the drift relatively infrequently, the presumption has arisen that they have a low predisposition to drift (Corbet, 1999, pp. 15, 394; Koetsier \& Bryan, 
1995; Rader, 1997; Suhling \& Müller, 1996), but this presumption could be premature. Odonates would be expected to occur at low densities in the drift relative to the many taxa of physically smaller and more abundant aquatic insects on which they prey (e. g. the Pyramid of Numbers concept of Elton [1927]), and with which their drift densities are often compared (DuBois \& Smith, 2016). To determine the actual predisposition of odonate nymphs to drift, drift densities should be compared with benthic densities across large areas, and under various conditions, which has not been rigorously done to my knowledge. Accurate sampling of benthic densities of riverine species of Odonata can be an arduous process because larvae are usually not randomly distributed; rather, they inhabit preferred types of microhabitat which can cause them to have clumped distributions. Quantitative sampling of larvae that are not randomly distributed requires either large numbers of sample replicates or the stratification of habitat types, or both, and can require considerable prior knowledge of preferred habitats. Further, because drifting animals travel for unknown distances, it can be difficult to make meaningful correlations between the drift and the benthos (Heaton, 1966). It seems reasonable to postulate that low benthic densities of odonates relative to other taxa could at least in part explain the low numbers usually found in the drift. Additionally, the relatively small drift nets commonly used by aquatic entomologists were not designed for, and might have compromised effectiveness for, capturing and retaining larger taxa, including the later instars of larger species of Odonata. Furthermore, some investigators have suggested that some riverine odonates, even those that have not been caught in the drift, might have conditional and potentially ecologically significant occurrences in the drift that can be inferred from indirect evidence.

While the broad topic of aquatic invertebrate drift has been well reviewed, the narrower topic of odonate drift has received scant attention. For this reason and because the presumption of a low predisposition of odonates to drift might be inaccurate, I reviewed the drift literature to synthesize published information about Odonata drift.

\section{Materials and methods}

I used the search terms "Odonata" and "drift" in Google Scholar (the first 40 pages returned) on 13 April 2020, and the references sections of found articles including those collected during my career-long interest in macroinvertebrate drift, to locate original research reports (peer-reviewed scientific literature as well as "gray" literature including books, dissertations, and theses) that documented the natural drift of larval Odonata. More than 400 drift-related reports were examined. I also received help from several colleagues to find some pertinent literature not written in English.

To construct a list of species documented in natural drift (Table 1) I did not include reviews, studies that focused on a specified taxon or group of taxa that did not include odonates, studies done in unnatural settings (e.g. artificial channels), or studies that sampled drift as an escape response from pollution, insecticides, or lampricide treatments, unless odonates were taken in pretreatment samples (e.g. DuBois \& Plaster, 1993; Kolton, MacMahon, Jeffrey, \& Beamish, 1986). However, I examined such articles to gain knowledge about the ecological processes, conditions, and intrinsic individual behaviors that might be valuable in understanding Odonata drift. A reasonable point could be made that by focusing primarily on the documentation of natural drift, the focus of this review is excessively narrow because riverine systems globally have usually been subjected to a wide variety of anthropogenic perturbations. However, at this early stage of our understanding of the topic, it is important to establish a benchmark of the taxa and the natural conditions under which odonates are predisposed to drift that can subsequently be built upon as our understanding deepens regarding anthropogenic influences on Odonata drift. 
Table 1. Taxonomic levels of Odonata larvae reported in the drift by reference number, with drift density (individuals $\mathrm{m}^{-3}$ ), if given ${ }^{1}$. If multiple dates, sites, or treatments were reported, the greatest value is given and is preceded by $\leq$.

\begin{tabular}{ll}
\hline Taxon & Reference number (individuals $\mathrm{m}^{-3}$ ) \\
\hline
\end{tabular}

ODONATA

\section{ZYGOPTERA}

Calopterygidae

Calopteryx spp.

C. aequabilis Say

C. splendens (Harris)

C. virgo (Linnaeus)

Echo spp.

Hetaerina spp.

H. americana (Fabricius)

Neurobasis spp.

Chlorocyphidae

Rhinocypha spp.

Coenagrionidae (formerly

Protoneuridae $)^{2}$

Coenagrionidae

Amphiagrion spp.

Argia spp.

A. concinna (Rambur)

A. moesta (Hagen)

A. vivida Hagen in Selys

Enallagma spp.

E. civile (Hagen)

E. cyathigerum (Charpentier)

E. exsulans (Hagen)

Ischnura spp.

I. verticalis (Say)

Pyrrhosoma nymphula (Sulzer)

Xanthocnemis zealandica

(McLachlan)

Euphaeidae

Euphaea spp.

Heteragrionidae

Heteragrion spp.

H. erythrogastrum Selys

Lestidae

Archilestes grandis Rambur

Lestes spp.

Megapodagrionidae

Platycnemididae

Platycnemis acutipennis Selys

P. pennipes (Pallas)
Benke et al. (1986) ( $\leq$ 0.06); Hornung (1982); Koetsier \& Bryan (1995); March et al. (2003); Muir (1990); Musetta-Lambert et al. (2019); Parker (1976); Perić et al. (2011); Pringle \& Ramirez (1998); Ramirez \& Pringle (2001) ( $\leq 0.04)$; Rodriguez-Barrios et al. (2007) ( $\leq$ 0.017); Shannon et al. (1996)

Benke et al. (1991) ( $\leq$ 0.139); Bishop \& Hynes (1969); Boyero et al. (2005); Brewin \& Ormero (1994); Holanov (1984); Rezende (2013) (0.003)

Edmonds-Brown et al. (2004); Henn et al. (2004); Kolton et al. (1986); Lobón-Cerviá et al. (2012) (0.002); Mendoza et al. (2018); Principe \& Corigliano (2006); Ramirez \& Pringle (2001) $(\leq 0.028)$

Dendy (1944); Kaller \& Hudson (2010); Perić et al. (2014)

Heaton (1966)

Cellot (1996); Elliott (1967); Prevot \& Prevot (1986) (0.001)

Weninger (1968)

Amila Faqhira \& Suhaila (2019)

Pringle \& Ramirez (1998); Ramirez \& Pringle (2001) (0.01)

Kennedy \& Benfield (1979)

Amila Faqhira \& Suhaila (2019)

Amila Faqhira \& Suhaila (2019)

Henn et al. (2004); Ramirez \& Pringle (2001) $(\leq 0.003)$

Benigno (2011); Gimenez et al. (2015) (0.27); Gray \& Fisher (1981); Keefer \& Maughan (1985); Larimore (1972); Mendoza et al. (2018); Morris et al. (1968); Prevot \& Prevot (1986) $(<0.005)$; Ramirez \& Pringle (2001) $(\leq 0.032)$; Rutter \& Ettinger (1977)

Day et al., (1992)

Bahuguna et al. (2019); Benigno (2011); Cloud (1973) (0.061); Day et al. (1992); Kaller \& Hudson (2010); Pringle \& Ramirez (1998); Ramirez \& Pringle (1998) (0.01)

Bass (2004)

DuBois \& Pratt (2017) $(<0.001)$; Kennedy \& Benfield (1979)

Heaton (1966)

Benigno (2011); Cloud (1973) (0.103); Kaller \& Hudson (2010); Obi \& Conner (1986) (0.001)

Kennedy \& Benfield (1979)

Cellot (1996)

DuBois \& Pratt $(2017)(<0.001)$

Day et al. (1992); Sanders (1976)

DuBois \& Pratt (2017) $(<0.001)$

Elliott (1967)

Boothroyd \& Dickie (1991)

Amila Faqhira \& Suhaila (2019); Bahuguna et al. (2019)

Pringle \& Ramirez (1998)

Pringle \& Ramirez (1998)

Wiseman et al. (1993)

Winnell \& Jude (1991)

Ramirez \& Pringle $(2001)(\leq 0.028)$

Boyero et al. (2005)

Cellot (1996) 
Table 1. Continued.

\begin{tabular}{ll}
\hline Taxon & Reference number (individuals $\mathrm{m}^{-3}$ ) \\
\hline
\end{tabular}

Platystictidae

Drepanosticta spp.

\section{ANISOPTERA}

Aeshnidae

Anax imperator Leach

Basiaeschna janata (Say)

Boyeria spp.

Gomphidae

Acrogomphus spp.

Dromogomphus spp.

D. spinosus Selys

Gomphidia bredoi (Schouteden)

Gomphidictinus spp.

Gomphus spp. ${ }^{3}$

Gomphurus fraternus (Say)

G. ventricosus (Walsh)

G. vastus (Walsh)

Hylogomphus spp.

Megalogomphus spp.

Onychogomphus spp.

O. forcipatus (Linnaeus)

O. uncatus (Charpentier)

Ophiogomphus spp.

O. anomalus Harvey

O. aspersus Morse

O. colubrinus Selys ${ }^{4}$

O. howei Bromley

O. rupinsulensis (Walsh)

O. severus Hagen

Phyllocycla spp.

Progomphus spp.

P. borealis McLachlan

P. obscurus (Rambur)

Stylurus spiniceps (Walsh)

Cordulegastridae

Cordulegaster boltonii (Donovan)

C. maculata Selys

Macromiidae

Didymops spp.

Macromia illinoiensis Walsh

M. taeniolata Rambur

Corduliidae

Epitheca princeps (Hagen) ${ }^{5}$

Neurocordulia spp.

N. yamaskanensis (Provancher)

Procordulia grayi (Selys)

Somatochlora minor Calvert in Harvey

Corduliidae/Libellulidae

Libellulidae

Brechmorhoga spp.

Libellula spp.
Amila Faqhira \& Suhaila (2019)

Benigno (2011); Benke et al. (1991) ( $\leq$ 0.153); Brewin \& Ormerod (1994); Edmonds-Brown et al. (2004); Holanov (1984); Rezende et al. (2013) (0.01)

Henn et al. (2014)

Cellot (1996)

DuBois \& Pratt (2017)

Kaller \& Hudson (2010)

Benson \& Pearson (1987); Hortle et al. (2005) (0.004); Lobón-Cerviá et al. (2012) (0.01); Mendoza et al. (2018); Pringle \& Ramirez (1998); Ramirez \& Pringle (2001) $(\leq 0.046)$; Zhang et al. (2010)

Amila Faqhira \& Suhaila (2019)

Obi \& Conner $(1986)(<0.001)$

DuBois \& Pratt $(2017)(<0.001)$

Müller et al. (2005)

Amila Faqhira \& Suhaila (2019); Bahuguna et al. (2019)

Day et al. (1992); Kaller \& Hudson (2010); Obi \& Conner (1986) $(<0.001)$

DuBois \& Pratt (2017)

DuBois \& Pratt (2017) (0.002)

Kennedy \& Benfield (1979)

DuBois \& Pratt (2017) (0.004)

Amila Faqhira \& Suhaila (2019)

Fenoglio et al. (2014)

Perić et al. (2014); Prevot \& Prevot (1986) $(\leq 0.002)$

Suhling (1994)

Cloud (1973) (0.055)

DuBois \& Pratt (2017) $(<0.001)$

Kennedy \& Benfield (1979)

DuBois \& Rackouski (1992)

DuBois \& Pratt (2017) (0.026); Kennedy \& Benfield (1979)

DuBois \& Pratt (2017) (0.007)

Heaton (1966)

Principe \& Corigliano (2006)

Kaller \& Hudson (2010); Principe \& Corigliano (2006)

Gray \& Fisher (1981)

DuBois \& Pratt $(2017)(<0.001)$

Kennedy \& Benfield (1979)

Johnson \& Johnson (1982)

Elliott (1967)

DuBois \& Pratt (2017) $(<0.001)$

Kaller \& Hudson (2010)

DuBois \& Pratt (2017) (0.001); Kennedy \& Benfield (1979)

Cowell \& Carew (1976)

Henn et al. (2014); Hortle et al. (2005)

Cowell \& Carew (1976)

Kaller \& Hudson (2010); Obi \& Conner (1986) $(<0.001)$

Kennedy \& Benfield (1979)

Towns (1978)

DuBoi \& Plaster (1993)

Benigno (2011)

Gimenez et al. (2015) ( $\leq 0.12)$; Henn et al. (2014); Lobón-Cerviá et al. (2012) (0.004); Ramirez \& Pringle (2001) $(<0.038)$

Pringle \& Ramirez (1998)

Obi \& Conner $(1986)(<0.001)$ 
Table 1. Continued.

\begin{tabular}{|c|c|}
\hline Taxon & Reference number (individuals $\mathrm{m}^{-3}$ ) \\
\hline Perithemis spp. & Obi \& Conner $(1986)(<0.001)$ \\
\hline Zygonyx spp. & Amila Faqhira \& Suhaila (2019); Bahuguna et al. (2019) \\
\hline \multicolumn{2}{|c|}{$\begin{array}{l}{ }^{1} \text { Not included are the density estimates given by Perić, Miliša, Kepčija, Primc-Habdija, and Habdija (2011) and Perić et al. (2014), because } \\
\text { their drift sampling was done in a unique setting (a moss-rich, karst, tufa-precipitating hydrosystem) and their density estimates were much } \\
\text { higher than the highest estimates reported in other studies. } \\
\text { 2 New World species of the former family Protoneuridae were sunk in Coenagrionidae after these articles were published. } \\
{ }^{3} \text { Now includes North American genera Gomphurus, Hylogomphus, and Phanogomphus. } \\
{ }^{4} \text { Incorrectly reported in the original article as Ophiogomphus carolus Needham. } \\
5 \text { Reported in original article as Epicordulia regina. }\end{array}$} \\
\hline
\end{tabular}

I was also interested in assessing how numbers of drifting odonates were reported, what the drift densities were, what taxonomic levels were determined, and in gaining insight on life stages in the drift and the environmental conditions associated with drifting. I thus compiled a reasonably comprehensive list of reports that mentioned natural drift of Odonata, but I do not presume that the effort recovered all studies that have done so. Articles in which drift of Odonata was reported (Table 1) are each preceded by an identifying number in bold font in the References Section.

\section{Results}

\section{Drifting of Odonata reported by taxon}

Drift of Odonata was documented at some taxonomic level in 63 reports (Table 1). Among these reports, 86 taxa ranging from order to species were reported, with 15 families, 44 genera, and 43 species documented. If the additional species and genera for which drift has been reasonably inferred are added (Table 2), then the number of known drifting genera would increase to 52 and the number of known drifting species to 56. In looking at how taxonomic determinations were reported (Table 1), the number of occurrences in the articles in which the taxon was the lowest one identified are in parentheses: order (12), suborder (12), family (36), genus (50), and species (49). Zygoptera ( 9 families) and Anisoptera (6 families) were both well represented. Gomphidae (13 genera) and Coenagrionidae (6 genera) were the most commonly noted families in the drift; they may have also been the most common families in the lotic systems in the geographic regions where most of the studies were done. In the many other articles on macroinvertebrate drift that I examined that did not mention odonates, I did not know if small numbers had been ignored or placed in an "other" category, or if the lotic systems studied had few odonates.

\section{Drift densities and other reported measures of Odonata drift}

Drift densities were reported in 13 articles for 31 odonate taxa (see exclusions in Table 1), the mean of which was a rather low $0.03 \mathrm{~m}^{-3}$ (range $<0.001-0.153 \mathrm{~m}^{-3}$ ), and nearly $90 \%$ of the reported drift densities were $<0.1 \mathrm{~m}^{-3}$ (Table 1). To put the $0.03 \mathrm{~m}^{-3}$ mean density value into some frame of reference, sampling a volume of water equivalent to that contained in an Olympicsize swimming pool $\left(\sim 2500 \mathrm{~m}^{-3}\right.$, assuming a nominal depth of $\left.2 \mathrm{~m}\right)$ would yield about 75 Odonata larvae. Drift densities for individual insect species in orders that frequently occur in the drift seldom exceed $100 \mathrm{~m}^{-3}$ (Waters, 1972), but they are usually much greater, often more than 100 times greater, than those reported for odonates. 
Odonata drift values are sometimes expressed as percent composition of the total drift, usually as frequency of occurrence, but sometimes as biomass or volume. In terms of frequency of occurrence, Odonata were usually less than 1\% (Amila Faqhira \& Suhaila, 2019; Brewin \& Ormerod, 1994; Cowell \& Carew, 1976; Edmonds-Brown, Copp, \& Majecki, 2004; Morris, Langemeier, Russell, \& Witt, 1968), invariably less than $10 \%$, and nearly always less than $4 \%$ (e.g. Benke, et al., 1986; Pringle \& Ramirez, 1998) of the total. Some investigators did not report a specific value, but from their data the percentage is found to be tiny. For example, Boyero, Valladolid, and Arauzo (2005) reported capturing nearly 9000 animals in the drift of a river in central Spain, but only two of them were odonates, and Parker (1976) caught more than 18,000 macroinvertebrates in drift nets placed in the Des Moines River (USA), but only one was an odonate. Rutter and Ettinger (1977) collected just two larvae of Coenagrionidae among 359 macroinvertebrates $(0.006 \%)$ in subsurface drift nets over deep water in a Pennsylvania (USA) river. Cellot (1996) reported that 87 odonates were collected in the drift from among 200,005 aquatic macroinvertebrates so collected $(0.04 \%)$ in the Rhône River (France). Slightly higher values were reported by Henn, Nichols, Zhang, and Bonner (2014), who found that odonates comprised $6.6 \%$ of the drift in central Texas (USA) streams, and that coenagrionids were common enough to show statistically significant differences among treatments (light additions). Further, Hortle, Chea, Bun, Em, and Thac (2005) found gomphid larvae to comprise nearly $9 \%$ of the total invertebrate drift in the Mekong River (Cambodia).

Because of their relatively large individual sizes compared to the individual sizes of other macroinvertebrate taxa that drift frequently, odonates, though not usually full grown, would still be expected to comprise a larger portion in biomass or volume totals than in frequency totals because individuals in other macroinvertebrate orders are also not usually full grown. For example, Benke, Parsons, and Dhar (1991) noted that Odonata and Megaloptera were relatively uncommon in the drift, but that their combined biomasses occasionally rivaled those of the more

Table 2. Odonata taxa for which drift was inferred in the original article. Explanation categories for inferred drift: (A) emergence sites located downstream of primary larval habitat, (B) reproductive activities upstream of where tenerals found, (C) larvae or exuviae found downstream of oviposition sites or adult flight, (D) adults seen flying mostly upstream, (E) recolonization of depopulated reaches presumed due to larval drift, (F) larvae found in stomachs of drift-feeding salmonids during high water, and $(\mathrm{G})$ species prone to drift accidentally at high flows in controlled settings (laboratory/artificial channel).

\begin{tabular}{|c|c|c|}
\hline Species/taxa & Explanation & Reference \\
\hline Calopteryx haemorrhoidalis (van der Linden) & $\mathrm{B}, \mathrm{D}$ & Beukema (2002) \\
\hline Coenagrion spp. & $\mathrm{F}$ & Cios (2007) \\
\hline Ischnura elegans (van der Linden) & $\mathrm{F}$ & Cios (2007) \\
\hline Erythromma najas (Hansemann) & $\mathrm{F}$ & Cios (2007) \\
\hline Platycnemis pennipes (Pallas) & $\mathrm{F}$ & Cios (2007) \\
\hline Aeshna grandis (Linnaeus) & $\mathrm{F}$ & Cios $(2007)$ \\
\hline Gomphus vulgatissimus (Linnaeus) & $\mathrm{F}, \mathrm{G}$ & Cios (2007); Schnauder et al. (2010) \\
\hline Phanogomphus quadricolor (Walsh) & A & Walker (1932) \\
\hline Onychogomphus forcipatus (Linnaeus) & $\mathrm{C}$ & Westermann (2017) \\
\hline Ophiogomphus cecilia (Fourcroy) & $\mathrm{F}$ & Cios (2007) \\
\hline Stylogomphus suzukii (Matsumura) & A & Arai $(1993)$ \\
\hline Cordulegaster spp. & $\mathrm{C}$ & McDowell and Naiman (1986); DuBois (2010) \\
\hline Cordulegaster insignis Schneider & $\mathrm{G}$ & Leipelt (2005); Kulijer and Boudot (2013) \\
\hline Antipodochlora braueri (Selys) & $\mathrm{C}$ & Winstanley (1980) \\
\hline Neurobasis awamena Michalski & $\mathrm{D}$ & Oppel (2006) \\
\hline Somatochlora metallica (van der Linden) & $\mathrm{F}$ & Cios (2007) \\
\hline Orthetrum spp. & $\mathrm{F}$ & Cios (2007) \\
\hline Sympetrum spp. & $\mathrm{F}$ & Cios (2007) \\
\hline Sympetrum sanguineum (Müller) & $\mathrm{F}$ & Cios (2007) \\
\hline Odonata assemblages & $\mathrm{E}$ & Buczynski et al. (2016) \\
\hline
\end{tabular}


common dipterans and crustaceans. Zhang et al. (2010) sampled in the Pearl River drainage basin (China) where they noted that gomphids made up only $3.2 \%$ of the night drift, but $63.5 \%$ of the total dry mass. Rodriguez-Barrios, Ospina-Torres, Gutierrez, and Ovalle (2007) measured Odonata biomass up to $0.069 \mathrm{mg} \mathrm{m}^{-3}$ in the few samples in which they captured odonates in a 1st order stream in the Eastern Hills (Columbia). Johnson and Johnson (1982) found that larvae of Cordulegaster spp. made up 3.3\% of the dry weight of the drift in an Adirondack Mountain stream (USA). Heaton (1966) found that odonates made up only $0.1 \%$ of the number of drifting macroinvertebrates in a Rocky Mountain (USA) river, but $3.1 \%$ of the drift volume.

\section{Relationships among Odonata drift, flow levels, and substrate particle sizes}

As is the case with aquatic macroinvertebrates generally (Benke et al., 1986), there is ample evidence that high water events cause accidental, catastrophic drift of Odonata, such that many more larvae drift than do on average, including some species not usually prone to drift. For example, Cios (2007) observed higher than average numbers of odonate larvae in the stomach contents of drift-feeding salmonids under high-flow conditions. Elliott (1967) caught small numbers of Pyrrhosoma nymphula and Cordulegaster boltonii in drift nets only during a severe spate. Kennedy and Benfield (1979) noted that both the diversity and numbers of Odonata in the drift increased during periods of rising water, and Benson and Pearson (1987) collected higher numbers of drifting gomphids during high water than low water. Interestingly, Cellot (1996) reported that macroinvertebrate taxa richness in the drift was highest during spates, but that total drift densities were less so, suggesting that spates caused the accidental drift of a few individuals of many taxa.

Leipelt (2005) showed experimentally that larvae of Cordulegaster insignis and C. bidentata Selys were more prone to drift than two other species of Cordulegaster when exposed to strong currents in an artificial stream, and they drifted for longer distances. These results led to the conclusion that these species would be restricted to habitats of low discharge and current velocity. Kulijer and Boudot (2013) cited Leipelt (2005) in explaining why the distribution of $C$. insignis was confined to areas with low discharge and current velocity, like springs and spring brooks. Schnauder, Rudnick, Garcia, and Aberle (2010) identified the shear stresses that caused a variety of benthic macroinvertebrates to drift in a small, tilting flume. They found that Calopteryx splendens and several species of Coenagrionidae maintained their hold on the sand substrate through high flows, but that Cordulia aenea (Linnaeus) and Gomphus vulgatissimus did not, the latter being one of only two taxa to drift at subcritical flow levels. Müller (1995) used an experimental channel to examine the effects of a range of critical flow velocities and substrate particle sizes (coarse to fine sand) on the intrinsic burrowing and drifting behaviors of the last four instars of Stylurus flavipes (Charpentier), G. vulgatissimus, and Ophiogomphus cecilia. He found that drift rates, critical flow velocities at which larvae entered the drift, and activity levels when drifting and burrowing differed among species. Drift frequencies increased with increasing flow velocities and were generally higher for substrates of coarse sand than medium sand for S. flavipes and G. vulgatissimus. Stronger currents were needed to induce drift in the finest substrates, and the risk of being accidentally caught in the drift was directly related to the depth of burrowing and the movement activity of the individual larvae (Suhling \& Müller, 1996). Once in the drift, European species of gomphids that burrow behaved differently $-S$. flavipes and Ophiogomphus cecilia quickly swam down to the substrate and burrowed into it, while G. vulgatissimus was less active and drifted for longer distances (Suhling \& Müller, 1996). Further, some investigators have suggested that high flows can cause "sediment saltation", which can increase macroinvertebrate drift (Culp, Wrona, \& Davies, 1986; Rosenberg \& Weins, 1978). 
Although high flows clearly cause some portion of the drift of Odonata, they are not responsible for all of it. Nocturnally biased drift of Odonata, which has been widely revealed in this review, has an active, behavioral component. Cloud (1973) reported relatively high drift densities of odonate taxa in a regulated river in Texas (USA) even though samples were only taken at low to moderate flow levels. Further, some investigators that reported moderate or high drift densities did not report that their samples were taken during high flows (DuBois \& Pratt, 2017; Hortle et al., 2005). Larvae of species of riverine gomphids that usually burrow into the substrate will occasionally leave the substrate to move to the low-flow boundary at the substrate-flow interface when molting or needing food, where they are more apt than usual to become dislodged by the current across a range of flow velocities (Müller, 1995). Conversely, Minshall and Winger (1968) found that a reduction in stream discharge resulted in increased numbers of benthic macroinvertebrates in the drift (none of the benthic taxa were odonates, however). At a practical level, it is likely that investigators tend to avoid sampling during high-flow conditions because of the increased logistical difficulties involved and the potential for safety issues, even though more odonates are likely to be drifting in those conditions.

\section{Diel, seasonal, and thermal patterns}

As with most other aquatic insects, drift of Odonata was highest right after dark (post-dusk; Bass, 2004; Benke et al., 1986; Cloud, 1973; Hortle et al., 2005; Johnson \& Johnson, 1982; Ramirez \& Pringle, 1998; Zhang et al., 2010), sometimes with a secondary peak in early morning (a bigeminus pattern). Nocturnal, behavioral drift activity is thought to be a means to reduce mortality caused by visual predators like fishes (the "risk of predation" hypothesis; Allan \& Castillo, 2007; Brewin \& Ormerod, 1994), but Pringle and Ramirez (1998) noted that other factors may also influence temporal drift patterns. For example, Müller (1995) noted that movement activity was highest at night for several species of European gomphids that habitually burrow into the substrate; more locomotive activity could mean more opportunities to become accidentally caught up in the drift.

Seasonally, Odonata drift was higher in summer and fall than in winter or early spring (Benke et al., 1986; Cloud, 1973; Suhling, 1994). Kaller and Hudson (2010), who sampled each month from June 2005 through May 2006 in a subtropical, coastal plain stream (Louisiana, USA), reported the peaks of Odonata drift during the summer months (June through August). Keefer and Maughan (1985) reported that drift of Coenagrionidae was significantly less during March (late winter transitioning to early spring in Georgia, USA) than during June, July, or September.

Drift of aquatic macroinvertebrates generally has been reported to increase with increasing water temperatures (Pearson \& Franklin, 1968; Wojtalik \& Waters, 1971); this could be true for odonates as well, but the data are presently insufficient to draw firm conclusions. Durrett and Pearson (1975) caught larvae of Ischnura, Enallagma, and Erythemis in the heated water of an effluent channel from a powerplant in Texas (USA), but densities were $<0.001 \mathrm{~m}^{-3}$ in all cases.

\section{Life stages of drifting Odonata}

The life stages of drifting Odonata larvae of multiple species were reported by DuBois and Pratt (2017), who used the methodology developed by Tennessen (2016) to determine instars. Of the 172 larvae they collected, life stages F-0 through $\leq$ F-4 were all represented, but only $17 \%$ of larvae were in the final instar. Larvae of Somatochlora minor collected in the drift of a softwater stream in Wisconsin (USA) by DuBois and Plaster (1993) were later reexamined by the senior author and determined to be in instars F-2 and F-3 (RBD, unpublished data). Suhling (1994) 
reported that most of the larvae of Onychogomphus uncatus he caught drifting were F-3 and F-4. Thus, the limited data based on these studies give instars F-2 through F-4 as most common in the drift. However, instars younger than F-4 were probably not consistently retained by the larger mesh size used by DuBois and Pratt (2017). These observations are roughly consistent with comments given in other studies that relate to the size composition of odonates in the drift. For example, Benigno (2011) reported that the Odonata she captured in drift nets were mostly immature and Benson and Pearson (1987) also mentioned capturing early instars. Bishop and Hynes (1969) reported that the few larvae of Zygoptera they captured in the drift were all less than $2 \mathrm{~mm}$ long - these had to have been early instars. Perić et al. (2014) measured body lengths of Calopteryx spp. and Onychogomphus forcipatus larvae (avg. $<4 \mathrm{~mm}$ in both cases) that again indicated that most were not later instars. Suhling and Müller (1996) hypothesized that smaller larvae could be more susceptible than larger larvae to being caught in currents and that they might drift faster. In sum, while data on life stages of Odonata in the drift remains scant, the emerging picture is consistent with that reported for other macroinvertebrates - that immature individuals make up most of the drift.

\section{Methods used to sample Odonata drift}

Most of the drift net deployments that were used to collect the odonates in the studies included in this review were like those typically used by aquatic entomologists, with some variation - they were fixed to the substrate and were of relatively small sizes (net openings $<0.15 \mathrm{~m}^{-2}$, lengths $<1 \mathrm{~m}$, and relatively fine mesh sizes of 250-500 $\mu \mathrm{m}$ ). Some of the investigators used nets larger than these "standard" nets (DuBois \& Pratt, 2017; Heaton, 1966; Hortle et al., 2005; Koetsier \& Bryan, 1995; Obi \& Conner, 1986; Shannon et al., 1996; Zhang et al., 2010). Larger nets should confer some advantages over smaller nets with smaller mesh sizes when sampling for larger, less common taxa including the ability to sample large volumes of water more quickly, being able to sample for longer periods of time without the nets clogging with debris (which creates back pressure that drifting larvae might be able to detect and avoid), and a reduced likelihood of larvae being able to escape once inside the nets (DuBois \& Pratt, 2017). Several other net types and deployments were also used to sample Odonata drift in these studies. Day, Anderson, and Grubaugh (1992) used small, planktonic "bongo" nets in deeper pools of the Mississippi River (USA) that were raised slowly through the entire vertical water column to obtain integrated samples. Hortle et al. (2005) used large, planktonic "bongo" nets deployed at fixed locations near the bottom and near the surface. In deep water, investigators sometimes deployed nets from boats or rafts (Day et al., 1992; Hortle et al., 2005; Rutter \& Ettinger, 1977; Shannon et al., 1996). DuBois and Rackouski (1992) collected drifting larvae of Ophiogomphus colubrinus that were retained in the catch barge of an inclined-screen salmonid smolt trap. The numbers of gear types and deployments in this review were too few to test the efficacy of these methods for capturing drifting odonates.

\section{Drifting of Odonata inferred}

I used a variety of types of data to infer the drift of some riverine odonate taxa in addition to those taxa that have been caught drifting. This inferred drift appears to be an ecologically significant part of the life history of some species (the reasons for drawing the inference, species involved, and citations are summarized in Table 2). For example, Arai (1993) noted that larvae of Stylogomphus suzukii inhabited upper reaches of mountain streams in Japan, but that exuviae were found along lower reaches; this led him to surmise that pre-emergent larvae somehow moved downstream. Westermann (2017) found that densities of exuviae of Onychogomphus forcipatus 
were highest along the lower reach of a river in Germany, but that adult abundance was much higher in the middle reach than the lower reach. He stated that this result could only be explained by downstream drift of a high proportion of larvae over a substantial distance, which was compensated for by upstream flights of imagoes. Walker (1932) inferred the downstream drift of eggs or young larvae of Phanogomphus quadricolor in an Ontario, Canada, stream because oviposition was observed at running water reaches, but exuviae were only found near quiet water below rapids. In another case, larvae of Antipodochlora braueri were found downstream of sites of oviposition and adult activity in a New Zealand mountain stream, which caused the author to posit that downstream drift of eggs or larvae was the reason (Winstanley, 1980). Several investigators gave drift as an explanation for finding larvae of Cordulegaster spp. downstream of oviposition sites (DuBois, 2010; McDowell \& Naiman, 1986). In yet another case, it was the presence of tenerals and immatures of Calopteryx haemorrhoidalis only along the lower reaches of a small stream in Spain that led Beukema (2002) to conclude that larval drift caused by strong currents regularly depleted the upper half of the stream. Buczynski et al. (2016) posited that the rapid recovery of dragonfly assemblages destroyed by dredging in a small, regulated Polish river was the result of larval drift. DuBois and Smith (2016) marked F-0 larvae of Ophiogomphus rupinsulensis during autumn in a northern Wisconsin (USA) river and recovered marked exuviae the following spring. Of 38 marked exuviae that were recovered, only one was found upstream of the site where marked larvae were released, while $60 \%$ had moved downstream from 8 to $60 \mathrm{~m}$. However, since most movement distances were relatively short $(<30 \mathrm{~m})$, the larvae could have drifted or crawled downstream.

Oppel (2006) measured substantial lifetime dispersal distances (1000-1300 m) of imagoes of Neurobasis awamena in a predominantly upstream direction in rainforest streams in New Guinea, which led to the conclusion that downstream drift of larvae compensates for this upstream movement in rapidly flowing streams. Similarly, Higashi and Ueda (1982) reported that tenerals of Calopteryx cornelia Selys tended to fly upstream. These observations are consistent with the "colonization cycle" proposed by Müller (1954), whereby upstream flight of adults of amphibiotic insects compensates for the downstream displacement of their larvae. This proposal has largely been validated since as an evolutionarily stable strategy (summarized by Kopp, Jeschke, \& Gabriel, 2001), but with some uncertainty involving the density dependence of drift and dispersal capabilities of some taxa (Humphries \& Ruxton, 2002). I note here that with strong-flying insects like odonates, some upstream movement of adults would likely be enough to compensate for upstream losses due to larval drift, even if the drift is not density dependent.

\section{Potential ecological significance of Odonata drift}

Odonata drift could function in the many ways that have been suggested for other insect taxa including escaping from unsuitable habitats to colonize new habitats and reducing crowding. These ideas are consistent with the finding that most Odonata drift is comprised of individuals that are less than full-grown. Clearly, drift could function to repopulate suitable but under-utilized downstream habitats in many settings. Among the specific examples included in this review, Benson and Pearson (1987) concluded that drift acts to disperse early instars of Odonata to areas of more suitable habitat. Gray and Fisher (1981) saw drift as a recolonization pathway for Progomphus borealis after summer flooding in a Sonoran Desert stream (Arizona, USA). The drift-net collections of many gomphid larvae in the Mekong River led Hortle et al. (2005) to speculate that the larvae were near the surface at night because they were looking for prey, including small fish, an active form of behavioral drift. This behavior is in concord with the observations of Hildebrand (1974) who suggested that increased activity in searching for food in low-food treatments resulted in increased drift of four macroinvertebrate taxa. Unfortunately, observations of 
Odonata in drift studies are currently still too few to draw comprehensive inferences about the ecological functions involved. Perhaps Odonata drift is too complex, and not enough is known about it, for it to neatly fall into currently defined categories.

\section{Conclusion}

This review has revealed that many species and genera of Odonata are known to drift, and the list will no doubt continue to grow. Drift densities, while often comparatively low, are not uniformly low depending on shear flows in microhabitats and the species-specific behaviors of larvae. Therefore, it should not necessarily be assumed that odonates have a low predisposition to drift, especially since data relating benthic and drift densities are presently insufficient to make the point with confidence. Further, it should not be assumed that drifting is an inconsequential part of the life history of riverine odonates, as the observations of numerous investigators cited in this review have illustrated. Most drifting odonates are not full grown, which means that their identification can be difficult and will likely remain so for some taxonomic groups. Substantial drift of Odonata occurs during high flows, but it is not limited to them. Other factors that influence Odonata drift undoubtedly exist, but they have not been fully elucidated.

Drift net collections are not usually made specifically to sample for odonates and the results of this review affirmed that large volumes of water must typically be strained to capture a modest number of specimens. The hopeful attempts by some investigators to more effectively sample larger taxa like odonates with nets larger than those typically used to sample insect drift have shown some advantages over the use of smaller nets with smaller mesh sizes, but the drift densities they calculated were not substantially higher than those reported in several other studies.

Despite these caveats, drift nets are relatively simple to set and maintain, so their use for sampling Odonata species presence, especially for some gomphids and coenagrionids, should not be entirely dismissed. Collections of exuviae on shore, and the collections of larvae with various types of actively deployed nets, are likely to be more productive and time-efficient than collections made with drift nets in most circumstances. However, despite the considerable usefulness of exuviae collections for sampling for gomphids (Corbet, 1999; DuBois, 2015; DuBois \& Pratt, 2017; Hardersen, Corezzola, Gheza, Dell'Otto, \& La Porta, 2017), exuviae are typically available only for relatively short windows of time. Further, exuviae of coenagrionids are often small, fragile, and challenging to identify. Active netting for larvae is effective if habitats of target species are known and river areas can be safely waded, but these tools are limited in river reaches with deep, slippery, or rocky areas that are not conducive to safe wading, or if large areas of diverse habitat must be sampled. If habitats that are difficult to wade are targeted, safer areas slightly downstream might be found where drift nets could be set, or drift nets could be deployed from small boats. Further advantages are that drift samples are relatively clean (they do not usually contain much vegetative debris), no habitat is destroyed, and it is a relatively efficient sampling technique. For example, Allan and Russek (1985) found for aquatic insects generally, fewer replicate samples were required in drift sampling (to obtain 95\% CL that are $\pm 50 \%$ of the mean) than are usually required in benthic sampling. Pringle and Ramirez (1998) noted that drift sampling is useful in biodiversity assessment because it provides integrated samples of various habitats, which is advantageous if the habitats of some species are unknown or difficult to sample. Boyero, Valladolid, and Arauzo (2005) noted seven odonate taxa that were taken in benthos samples that were not taken in the drift, but that the single species taken in the drift was not taken in the benthos. Thus, drift sampling has been viewed as a complementary tool in the assessment of aquatic invertebrate assemblages generally (Callisto \& Goulart, 2005), and this could be true for odonates as well. 


\section{Acknowledgments}

Funding for this research was provided by the Wisconsin Department of Natural Resources. I benefitted from the improvements suggested by two reviewers and the content editor, and from discussions on Odonata drift with K. Tennessen.

\section{References}

Adamus, P. R., \& Gaufin, A. R. (1976). A synopsis of Nearctic taxa found in aquatic drift. American Midland Naturalist, 95, 198-204. doi: 10.2307/2424247

Allan, J. D., \& Castillo, M. M. (2007). Stream ecology: Structure and function of running waters (2nd ed.). Dordrecht, Netherlands: Springer.

Allan, J. D., \& Russek, E. (1985). The quantification of stream drift. Canadian Journal of Fisheries and Aquatic Sciences, 42, 210-215. doi: 10.1139/f85-028

Amila Faqhira, Z., \& Suhaila, A. H. (2019). Drift pattern of tropical stream insect: understanding the aquatic insects movement. Serangga, 24(1), 1-10. Retrieved from http://ejournal.ukm.my/serangga/article/view/30835/9467

Anderwald, P. H., Konar, M., \& Humpesch, U. H. (1991). Continuous drift samples of macroinvertebrates in a large river, the Danube in Austria. Freshwater Biology, 25, 461-476. doi: 10.1111/j.1365-2427.1991.tb01389

Arai, Y. (1993). Do larvae of a dragonfly, Stylogomphus suzukii, migrate downstream? Abstracts of papers read at the Twelfth International Symposium of Odonatology, Osaka.

Bahuguna, P., Joshi, H. K., \& Kumar, K. (2019). A report on drifting behaviour of Odonata (aquatic insects) in Kyunja Gad, a spring fed tributary of River Mandakini, Chamoli Garhwal, Uttarakhand. Journal of Mountain Research, 14(2), 63-67. Retrieved from https://www.researchgate.net/profile/Dr_Koshal_Kumar/publication/338854274

Bass, D. (2004). Diurnal stream drift of benthic macroinvertebrates on the small oceanic island of Dominica, West Indies. Caribbean Journal of Science, 40, 245-252. Retrieved from https://www.researchgate.net/profile/David_Bass3/ publication/267546553

Benigno, G. M. (2011). Invertebrate drift in neighboring perennial and seasonal tributaries of the Sacramento River. MS Thesis, California State University, Chico. Retrieved from http://citeseerx.ist.psu.edu/viewdoc/download?doi $=10$. 1.1.454.5468\&rep $=$ rep1\&type $=$ pdf

Benke, A. C., Hunter, R. J., \& Parrish, F. K. (1986). Invertebrate drift dynamics in a subtropical blackwater river. Journal of the North American Benthological Society, 5, 173-190. doi: 10.2307/1467705

Benke, A. C., Parsons, K. A., \& Dhar, S. M. (1991). Population and community patterns of invertebrate drift in an unregulated Coastal Plain river. Canadian Journal of Fisheries and Aquatic Sciences, 48, 811-823. doi: 10.1139/ f91-097

Benson, L. J., \& Pearson, R. G. (1987). The role of drift and effect of season on macroinvertebrate colonization of implanted substrata in a tropical Australian stream. Freshwater Biology, 18, 109-116. doi: 10.1111/ j.1365-2427.1987.tb01299

Beukema, J. J. (2012). Changing distribution patterns along a stream in adults of Calopteryx haemorrhoidalis (Odonata: Calopterygidae): a case of larval-drift compensation? International Journal of Odonatology, 5, 1-14. doi: $10.1080 / 13887890.2002 .9748173$

Bishop, J. E., \& Hynes, H. B. N. (1969). Downstream drift of the invertebrate fauna in a stream ecosystem. Archiv fur Hydrobiologie, 66, 56-90.

Boothroyd, I. K. G., \& Dickie, B. N. (1991). Macroinvertebrate drift and community colonization on perspex artificial substrates in the Ohinemuri River, New Zealand. New Zealand Journal of Marine and Freshwater Research, 25, 167-176. doi: 10.1080/00288330.1991.9516467

Boyero, L., Valladolid, M., \& Arauzo, M. (2005). Dynamics of invertebrate benthic communities and drift in a regulated river of central Spain. International Review of Hydrobiology, 90, 392-411. doi: 10.1002/iroh.200410805.

Brewin, P. A., \& Ormerod, S. J. (1994). Macroinvertebrate drift in streams of the Nepalese Himalaya. Freshwater Biology, 32, 573-583. doi: 10.1111/j.1365-2427.1994.tb01148

Brittain, J. E., \& Eikeland, T. J. (1988). Invertebrate drift - a review. Hydrobiologia, 166, 77-93. doi: 10.1007/ BF00017485

Buczynski, P., Zawal, A., Buczynska, E., Stepien, E., Dabkowski, P., Michonski, G., Szlauer-Lukaszewska, A., Pakulnicka, J., Stryjecki, R., \& Czachorowski, S. (2016). Early recolonization of a dredged lowland river by dragonflies (Insecta: Odonata). Knowledge \& Management of Aquatic Ecosystems, 417, 43. doi: 10.1051/kmae/2016030

Callisto, M. \& Goulart, M. (2005). Invertebrate drift along a longitudinal gradient in a Neotropical stream in Serra do Cipo National Park, Brazil. Hydrobiologia, 539, 47-56. doi: 10.1007/s10750-004-3245-4

Cellot, B. (1996). Influence of side arms on aquatic macroinvertebrate drift in the main channel of a large river. Freshwater Biology, 35, 149-164. doi: 10.1046/j.1365-2427.1996.00490.x

Cios, S. (2007). Odonata as food of fish. Odonatrix. Biuletyn Sekcji Odonatologicznej Polskiego Towarzystwa Entomologicznego, 3(1), 1-8. Retrieved from https://www.infona.pl/resource/bwmeta1.element.agro-1d3c1364-1f4f-4e028bb4-3be98cace 881

Cloud, T. J. (1973). Drift of aquatic insects in the Brazos River, Texas. MS Thesis, North Texas State University, Denton.

Corbet, P. S. (1999). Dragonflies: behavior and ecology of Odonata. Ithaca, NY: Cornell University Press.

Cowell, B. C., \& Carew, W. C. (1976). Seasonal and diel periodicity in the drift of aquatic insects in a subtropical Florida stream. Freshwater Biology, 6, 587-594. doi: 10.1111/j.1365-2427.1976.tb01648 
Culp, J. M., Wrona, F. J., \& Davies, R. W. (1986). Response of stream benthos and drift to fine sediment deposition versus transport. Canadian Journal of Zoology, 64, 1345-1351. doi: 10.1139/z86-200

Day, D. M., Anderson, R. V., \& Grubaugh, J. W. (1992). Macroinvertebrate drift: seasonal and habitat associations in Pool 19, Mississippi River. Journal of Freshwater Ecology, 7, 181-190. doi: 10.1080/02705060.1992.9664683

Dendy, J. S. (1944). The fate of animals in stream drift when carried into lakes. Ecological Monographs, 14, $333-357$. doi: $10.2307 / 1948447$

Dimond, J. B. (1967). Evidence that drift of stream benthos is density related. Ecology, 48, 855-857. doi: 10.2307/ 1933744

DuBois, B. (2010). Cordulegaster maculata (Twin-spotted Spiketail) nymphs in a natural drainage lake in Wisconsin. Argia, 22(1), 6-7. Retrieved from https://www.dragonflysocietyamericas.org/en/publications

DuBois, R. B. (2015). Detection probabilities and sampling rates for Anisoptera exuviae along river banks: influences of bank type, prior precipitation, and exuviae size. International Journal of Odonatology, 18, 205-215. doi: 10.1080/13887890.20151045560

DuBois, R. B., \& Plaster, S. D. (1993). Effects of lampricide treatment on macroinvertebrate drift in a small, softwater stream. Hydrobiologia, 263, 119-127. doi: 10.1007/BF00006208

DuBois, R. B., \& Pratt, D. M. (2017). Species and life stages of Odonata collected in large drift nets in two Wisconsin rivers. Great Lakes Entomologist, 50, 11-16. Retrieved from https://scholar.valpo.edu/tgle/vol50/iss1/3

DuBois, R. B., \& Rackouski, M. L. (1992). Seasonal drift of Lethocerus americanus (Hemiptera: Belostomatidae) in a Lake Superior tributary. Great Lakes Entomologist, 25, 85-89. Retrieved from https://www.researchgate.net/profile/ Robert_Dubois6/publication/283081077

DuBois, R. B., \& Smith, W. A. (2016). Pre-emergent movements and survival of F-0 larvae of Ophiogomphus rupinsulensis (Odonata: Gomphidae) in a northern Wisconsin river. International Journal of Odonatology, 19, 83-93. doi: 10.1080/13887890.2016.1183525

Durrett, C. W., \& Pearson, W. D. (1975). Drift of macroinvertebrates in a channel carrying heated water from a powerplant. Hydrobiologia, 46, 33-43. doi: 10.1007/BF00038725

Edmonds-Brown, V., Copp, G. H., \& Majecki, J. (2004). Diel patterns of drift by macroinvertebrates in the River Lee (Hertfordshire) during low discharge. The London Naturalist, 83, 145-157. doi: 10.1.1.177.5923\&rep = rep1\&type $=\mathrm{pdf}$

Elliott, J. M. (1967). Invertebrate drift in a Dartmoor stream. Archiv fur Hydrobiologie, 63, 202-237.

Elton, C. (1927). The animal community (Chapter 5). In C. Elton (Ed.), Animal ecology. London: Sidgwick \& Jackson. Retrieved from http://www.lancaster.ac.uk/users/philosophy/awaymave/onlineresources/animal\%20community.pdf

Fenoglio, S., Bo, T., Gallina, G., \& Cucco, M. (2004). Vertical distribution in the water column of drifting stream macroinvertebrates. Journal of Freshwater Ecology, 19, 485-492. doi: 10.1080/02705060.2004.9664923

Fleituch, T. (1985). Macroinvertebrate drift in the middle course of the River Dunajec (Southern Poland). Acta Hydrobiologica, 27, 49-61.

Gimenez, B. C. G., Lansac-Tôha, F. A., \& Higuti, J. (2015). Effects of land use on the composition, diversity and abundance of insects drifting in neotropical streams. Brazilian Journal of Biology, 75, 52-59. doi: 10.1590/ 1519-6984.03914

Gray, L. J., \& Fisher, S. G. (1981). Postflood recolonization pathways of macroinvertebrates in a lowland Sonoran Desert stream. American Midland Naturalist, 106, 249-257. doi: 10.2307/2425161

Hardersen, S., S. Corezzola, G. Gheza, A. Dell'Otto, \& G. La Porta. 2017. Sampling and comparing odonate assemblages by means of exuviae: statistical and methodological aspects. Journal of Insect Conservation, 21, 207-218. doi: 10.1007/s10841-017-9969-z

Heaton, J. R. (1966). The benthos and drift fauna of a riffle in the Madison River, Yellowstone National Park. PhD Thesis, Montana State University, Bozeman. doi: 10.1.1.956.6875\&rep = rep1\&type $=$ pdf

Henn, M., Nichols, H., Zhang, Y., \& Bonner, T. H. (2014). Effect of artificial light on the drift of aquatic insects in urban central Texas streams. Journal of Freshwater Ecology, 29, 307-318. doi: 10.1080/02705060.2014.900654

Higashi, K. \& T. Ueda. (1982). Territoriality and movement patterns in a population of Calopteryx cornelia. Odonatologica, 11, 129-138. Retrieved from http://natuurtijdschriften.nl/record/591575

Hildebrand, S. G. (1974). The relation of drift to benthos density and food level in an artificial stream. Limnology and Oceanography, 19, 951-957. doi: 10.4319/10.1974.19.6.0951

Holanov, S. H. (1984). The effects of current speed and food on non-catastrophic drift with reference to the ecology of Aravaipa Creek, Arizona. PhD Dissertation, University of Arizona, Tucson. Retrieved from http://arizona. openrepository.com/arizona/bitstream/10150/187772/1/azu_td_8424926_sip1_m.pdf

Hornung, T. M. (1982). The effects of stream canopy removal on macroinvertebrate communities in Tarr Creek, Monroe County, Wisconsin. MS Thesis, University of Wisconsin - La Crosse. Retrieved from https://minds. wisconsin.edu/bitstream/handle/1793/56788/HornungThomas1982.pdf?sequence $=1$

Hortle, K. G., Chea, T., Bun, R., Em, S., \& P. Thac, P. (2005). Drift of fish juveniles and larvae and invertebrates over 24-hour periods in the Mekong River at Phnom Penh, Cambodia. Proceedings of the $6^{\text {th }}$ Technical Symposium on Mekong Fisheries, Pakse, Lao. In MRC conference series (No. 5). Mekong River Commission, Vientiane (Lao PDR 26-28 November 2003). Retrieved from http://www.mekonginfo.org/assets/midocs/ 0002352-biota-drift-of-fish-juveniles-and-larvae-and-invertebrates-over-24-hour-periods-in-the-mekong-river-atphnom-penh-cambodia.pdf

Humphries, S., \& Ruxton, G. D. (2002). Is there really a drift paradox? Journal of Animal Ecology, 71, 151-154. doi: $10.1046 / \mathrm{j} .0021-8790.2001 .00579$ 
Johnson, J. H., \& Johnson, E. Z. (1982). Diel foraging in relation to available prey in an Adirondack Mountain stream fish community. Hydrobiologia, 96, 97-104. doi: 10.1007/BF00006282

Kaller, M. D., \& Hudson, J. D. (2010). Phenological partitioning among drifting insect genera within families in a subtropical, coastal plain stream. (Louisiana, USA). Journal of Freshwater Ecology, 25, 607-615. doi: $10.1080 / 02705060.2010 .9664410$

Keefer, L., \& Maughan, O. E. (1985). Effects of headwater impoundment and channelization on invertebrate drift. Hydrobiologia, 127, 161-169. doi: 10.1007/BF00004194

Kennedy, J. H., \& Benfield, E. F. (1979). Odonata drift in a large warmwater Appalachian river. Abstracts of papers read at the Fifth International Symposium of Odonatology, Montreal.

Koetsier, P., \& Bryan, C. F. (1995). Effects of abiotic factors on macroinvertebrate drift in the lower Mississippi River, Louisiana. American Midland Naturalist, 134, 63-74. doi: 10.2307/2426483

Koetsier, P., \& Bryan, C. F. (1996). Is macroinvertebrate drift a density-dependent mechanism of the benthos in the lower Mississippi River. Journal of Freshwater Ecology, 11, 1-10. doi: 10.1080/02705060.1996.9663488

Kolton, R. J., MacMahon, P. D., Jeffrey, K. A., \& Beamish, T. W. H. (1986). Effects of the lampricide, 3trifluoromethyl-4-nitrophenol (TFM) on the macroinvertebrates of a hardwater river. Hydrobiologia, 139, $251-267$. doi: 10.1007/BF00028296

Kopp, M., Jeschke, J. M., \& Gabriel, W. (2001). Exact compensation of stream drift as an evolutionarily stable strategy. Oikos, 92, 522-530. doi: 10.1034/j.1600-0706.2001.920313

Kulijer, D., \& Boudot, J.-P. (2013). First evidence of the occurrence of Cordulegaster insignis Schneider, 1845 in Serbia (Anisoptera: Cordulegastridae). Odonatologica, 42, 55-62. Retrieved from https://www.researchgate.net/profile/ Jean-Pierre_Boudot/publication/255968911

Larimore, R. W. (1972). Daily and seasonal drift of organisms in a warmwater stream (Research Report, 55). University of Illinois Water Resources Center.

Leipelt, K. G. (2005). Behavioural differences in response to current: implications for the longitudinal distribution of stream odonates. Archiv fur Hydrobiologie, 163, 81-100. doi: 10.1127/0003-9136/2005/0163-0081

Lobón-Cerviá, J., Rezende, C. F., \& Castellanos, C. (2012). High species diversity and low density typify drift and benthos composition in neotropical streams. Fundamental and Applied Limnology, 181, 129-142. doi: 10.1127/ $1863-9135 / 2012 / 0242$

March, J. G., Benstead, J. P., Pringle, C. M., \& Luckymis, M. (2003). Benthic community structure and invertebrate drift in a Pacific island stream, Kosrae, Micronesia. Biotropica, 35, 125-130. Retrieved from http://www.jstor.org/stable/30043042

McDowell, D. M., \& Naiman, R. J. (1986). Structure and function of a benthic invertebrate stream community as influenced by beaver (Castor canadensis). Oecologia, 68, 481-489. doi: 10.1007/BF00378759

Mendoza, M. D., Montoya, J. V., \& Perez, B. Y. (2018). Diel periodicity of aquatic macroinvertebrate drift in a coastal stream in northern Venezuela. Neotropical Biodiversity, 4, 45-54. doi: 10.1080/23766808.2018.1450056

Minshall, G. W., \& Winger, P. V. (1968). The effect of reduction in stream flow on invertebrate drift. Ecology, 49, 580-582. doi: $10.2307 / 1934133$

Morris, L. A., Langemeier, R. N., Russell, T. R., \& Witt, A. (1968). Effects of main stem impoundments and channelization upon the limnology of the Missouri River, Nebraska. Transactions of the American Fisheries Society, 97, 380-388. doi: 10.1577/1548-8659(1968)97[380:EOMSIA]2.0CO;2

Muir, W. D. (1990). Macroinvertebrate drift abundance below Bonneville Dam and its relation to juvenile salmonid food habits (MS Thesis, Paper 4108). Portland State University, Portland, OR. doi: 10.15760/etd.5992

Müller, K. (1954). Investigations on the organic drift in North Swedish streams. Report of the Institute for Freshwater Research Drottningholm, 34, 133-148.

Müller, K. (1974). Stream drift as a chronobiological phenomenon in running water ecosystems. Annual Review of Ecology and Systematics, 5, 309-324. doi: 10.1146/annurev.es.05.110174.001521

Müller, O. (1995). Ökologische Untersuchungen an Gomphiden (Odonata: Gomphidae) unter besonderer Berïcksichtigung ihrer Larvenstadien (Dissertation, Humboldt Universität Berlin). Göttingen: Verlag Cuvillier.

Müller, O., Clausnitzer, V., Grabow, K., Vick, G., \& Suhling, F. (2005). Description of the final stadium larvae of African Gomphidia (Odonata: Gomphidae). International Journal of Odonatology, 8, 233-241. doi: 10.1080/ 13887890.2005 .9748255

Musetta-Lambert, J., Kreutzweiser, D., \& Sibley, P. (2019). Influence of wildfire and harvesting on aquatic and terrestrial invertebrate drift patterns in boreal headwater streams. Hydrobiologia, 834, 27-45. doi: 10.1007/s10750-019-3907-x

Obi, A., \& Conner, J. V. (1986). Spring and summer macroinvertebrate drift in the Lower Mississippi River, Louisiana. Hydrobiologia, 139, 167-175. doi: 10.1007/BF00028100

Oppel, S. (2006). Site fidelity and dispersal of adult Neurobasis awamena Michalski in tropical rainforest streams in Papua New Guinea (Zygoptera: Calopterygidae). Odonatologica, 35, 331-339. Retrieved from http://natuurtijdschriften.nl/search?identifier $=592564$

Parker, C. E. (1976). A study of the macroinvertebrate drift in the Des Moines River. MA Thesis, Drake University, Des Moines, Iowa. Retrieved from http://escholarshare.drake.edu/handle/2092/839

Pearson, W. D., \& Franklin, D. R. (1968). Some factors affecting drift rates of Baetis and Simuliidae in a large river. Ecology, 49, 75-81.

Perić, M. S., Dražina, T., Špoljar, M., Radanović, I., Primc, B., \& Habdija, I. (2014). Meiofauna constitute a considerable portion of invertebrate drift among moss-rich patches within a karst hydrosystem. Biologia, 69, 363-380. doi: 10.2478/s11756-013-0323-y 
Perić, M. S, Miliša, M., Kepčija, R. M., Primc-Habdija, B., \& Habdija, I. (2011). Seasonal and fine-scale spatial drift patterns in a tufa-depositing barrage hydrosystem. Fundamental and Applied Limnology, 178, 131-145. doi: 10.1127/1863-9135/2011/0178-0131

Prevot, G., \& Prevot, R. (1986). Impact d'une crue sur la communauté d'invertébrés de la Moyenne Durance. Rôle de la dérive dans la reconstitution du peuplement du chenal principal. Annales de limnologie, 22, 89-98. doi: 10.1051/limn/1986010

Principe, R. E., \& Corigliano, M. C. (2006). Benthic, drifting and marginal macroinvertebrate assemblages in a lowland river: temporal and spatial variations and size structure. Hydrobiologia, 553, 303-317. doi: 10.1007/s10750-005-0694-3

Pringle, C. A., \& Ramirez, A. (1998). Use of both benthic and drift sampling techniques to assess tropical stream invertebrate communities along an altitudinal gradient, Costa Rica. Freshwater Biology, 39, 359-373. doi: 10.1046/j.1365-2427.1998.00311

Rader, R. B. (1997). A functional classification of the drift: traits that influence invertebrate availability to salmonids. Canadian Journal of Fisheries and Aquatic Sciences, 54, 1211-1234. doi: 10.1139/f97-025

Ramirez, A., \& Pringle, C. M. (1998). Invertebrate drift and benthic community dynamics in a lowland neotropical stream, Costa Rica. Hydrobiologia, 386, 19-26. doi: 10.1023/A:1003409927131

Ramirez, A., \& Pringle, C. M. (2001). Spatial and temporal patterns of invertebrate drift in streams draining a neotropical landscape. Freshwater Biology, 46, 47-62. doi: 10.1111/j.1365-2427.2001.00636

Rezende, C. F., Lobón-Cerviá, J., Caramaschi, E. P., \& Mazzoni, R. (2013). Trophic ecology of two benthivorous fishes in relation to drift and benthos composition in a pristine Serra do Mar stream (Rio de Janeiro, Brazil). Fundamental and Applied Limnology, 183, 163-175. doi: 10.1127/1863-9135/2013/0430

Rodriguez-Barrios, J., Ospina-Torres, R., Gutierrez, J. D., \& Ovalle, H. (2007). Densidad y biomasa de macroinvertebrados acuaticos derivantes en una quebrada tropical de montana (Bogota, Columbia). Caldasia, 29, $397-412$. Retrieved from https://www.jstor.org/stable/23641776.

Rosenberg. D. M., \& Wiens, A. P. (1978). Effects of sediment addition on macrobenthic invertebrates in a northern Canadian river. Water Research, 12, 753-763. doi: 10.1016/0043-1354(78)90024-6

Rutter, R. P., \& Ettinger, W. S. (1977). Method for sampling invertebrate drift from a small boat. Progressive FishCulturist, 39, 49-52. doi: 10.1577/1548-8659(1977)39[49:MFSIDF]2.0.CO;2

Sanders, D. F. (1976). Effects of stream channelization on aquatic macroinvertebrates, Buena Vista Marsh, Portage County, Wisconsin. MS Thesis, University of Wisconsin - Stevens Point, Stevens Point, WI. Retrieved from http://digital.library.wisc.edu/1793/79465

Schnauder, I., Rudnick, S., Garcia, X.-F., \& Aberle, J. (2010). Incipient motion and drift of benthic invertebrates in boundary shear layers. In A. Dittrich, K. Koll, J. Aberle, \& P. Geisenhainer (Eds.), River Flow 2010 (pp. 1453-1462). Karlsruhe: Bundesanstalt für Wasserbau. Retrieved from https://hdl.handle.net/20.500.11970/99801

Shannon, J. P., Blinn, D. W., Benenati, P. L., \& Wilson, K. P. (1996). Organic drift in a regulated desert river. Canadian Journal of Fisheries and Aquatic Sciences, 53, 1360-1369. doi: 10.1139/f96-062

Suhling, F. (1994). Einnischungsmechanismen der Larven von Onychogomphus uncatus (Charpentier) (Odonata: Gomphidae) (Dissertation). Technische Universitat, Braunsch-weig. Gottingen: Cuvillier-Verlag.

Suhling, F., \& Müller, O. (1996). Die Flussjungfern Europas. - Die neue Brehm-Bücherei. Bd. 628. Magdeburg (Westarp Wissenschaften) Retrieved from https://www.nhbs.com/die-flussjungfern-europas-the-gomphidae-of-europe-book.

Tennessen, K. J. (2016). A method for determining stadium number of late stage dragonfly nymphs (Odonata: Anisoptera). Entomological News, 126, 299-306. doi: 10.3157/021.126.0407

Tennessen, K. J. (2019). Dragonfly Nymphs of North America: An Identification Guide. Switzerland: Springer Nature.

Towns, D. R. (1978). Some little-known benthic taxa from a northern New Zealand river and its tributaries. New Zealand Entomologist, 6, 409-419. doi: 10.1080/00779962.1978.9722306

Walker, E. M. (1932). The nymph of Gomphus quadricolor Walsh (Odonata). Canadian Entomologist, 64, 270-273. doi: 10.4039/Ent64270-12

Waters, T. F. (1965). Interpretation of invertebrate drift in streams. Ecology, 46, 327-334. doi: 10.2307/1936336

Waters, T. F. (1972). The drift of stream insects. Annual Review of Entomology, 17, 253-267. doi: 10.1146/annurev. en.17.010172.001345

Weninger, G. (1968). Vergleichende Drift-Untersuchungen an niederösterreichischen Fliessgewässern (Flysch-, Gneis, Kalkformation). Schweizerische Zeitschrift fur Hydrologie, 30, 138-185 (not seen; cited by Cios 2007). doi: 10.1007/BF02503081

Westermann, K. (2017). Zur drift de larven der Kleinen Zangenlibelle (Onychogomphus forcipatus) im fluss-system Elz-Dreisam-Leopoldskanal-Restrhein. Naturschutz südl. Oberrhein, 9, 141-154.

Winnell, M. H., \& Jude, D. J. (1991). Northern large-river benthic and larval fish drift: St. Marys River, USA/Canada. Journal of Great Lakes Research, 17, 168-182. doi: 10.1016/S0380-1330(91)71354-3

Winstanley, W. J. (1980). A preliminary account of the habitat of Antipodochlora braueri (Odonata: Corduliidae) in New Zealand. New Zealand Entomologist, 7, 141-148. doi: 10.1080/00779962.1980.9722358

Wiseman, S. W., Cooper, S. D., \& Dudley, T. L. (1993). The effects of trout on epibenthic odonate naiads in stream pools. Freshwater Biology, 30, 133-145. doi: 10.1111/j.1365-2427.1993.tb00794

Wojtalik, T., \& Waters, T. (1971). Some effects of heated water on the drift of two species of stream invertebrates. Transactions of the American Fisheries Society, 99, 782-788. doi: 10.1577/1548-8659(1970)99 < 782:SEOHWO > 2.0. $\mathrm{CO} ; 2$

Zhang, Y., Dudgeon, D., Cheng, D., Thoe, W., Fok, L., Wang, Z., \& Lee, J. H. W. (2010). Impacts of land use and water quality on macroinvertebrate communities in the Pearl River drainage basin, China. Hydrobiologia, 652, 71-82. doi: $10.1007 / \mathrm{s} 10750-010-0320-\mathrm{x}$ 